\title{
Septicine Inhibits the Production of Inflammatory Mediators in Lipopolysaccharide- Stimulated Murine Macrophages
}

Geun-Mook Park and Jin-Kyung Kim*

Department of Biomedical Science, College of Natural Science, Cathdic University of Daegu, Gyeoungsan-Si 700-712, Korea

Received July 25, 2011 /Revised August 26, 2011 /Accepted August 30, 2011

\begin{abstract}
Anti-inflammatory activities of septicine, a natural alkaloid product present in the leaves and stems of Tylophora ovata, were evaluated in lipopolysaccharide (LPS)-stimulated murine macrophages, RAW264.7 cells. Treatment with septicine inhibited LPS-induced nitric oxide (NO), inflammatory cytokines, tumor necrosis factor- $a$ and interleukin- 6 production in a concentration-dependant manner. In addition, septicine suppressed the expression of inducible NO synthase. These results suggest that the anti-inflammatory activities of septicine might be attributed to the inhibition of NO, iNOS and cytokine expression.
\end{abstract}

Key words : Inflammation, lipopolysaccharide, macrophages, septicine

\section{서 론}

선천면역(innate immunity)은 박테리아나 바이러스 감염, 스트레스에 대해 방어 할 수 있도록 다양하고 효과적인 작용 기전을 통하여 빠르게 활성화 되는 고전적 숙주방어이다. 그 러나 지속적이며 과도한 면역반응은 조직손상을 촉진하여 일 부에서는 패혈증과 만성염증을 유도한다[6]. 염증은 외부로부 터의 자극에 대한 생체조직의 방어 반응의 하나로, 조직변질, 순환장애와 조직증식의 세 가지를 병발하는 생체의 변화이다 $[1,6]$. 생체에서 염증반응이 개시되면 다양한 염증매개물질들이 생성되어 발적, 발열, 종창, 동통, 기능장애 등의 증상이 나타난 다[1]. 염증반응에 핵심적인 역할을 담당하고 있는 대식세포 (macrophage)는 선천면역뿐만 아니라 적응면역(adaptive immunity) 등 다양한 숙주반응에 관여하여 항상성 유지에 관여 하는 것으로 알려져 있다[13]. 대식세포는 lipopolysaccharide (LPS)와 같은 외부의 자극에 의해 염증반응을 조절하는 핵심 적인 전사인자를 활성화 시키며, 그 결과 inducible nitric oxide synthase (iNOS), cyclooxygenase-2 (COX-2) 등과 같은 효 소를 발현시켜 nitric oxide (NO), prostaglandin (PG)E 2 및 염 증성 사이토카인(cytokine) 등의 염증매개물질들을 생성한다 [3,13]. 이러한 염증매개물질들은 감염초기에 세균을 죽이거나 종양을 제거시키는 역할을 담당하지만, 염증매개물질들의 과 도한 형성은 만성염증을 유발시키게 되며 조직의 손상, 유전 자 변이 및 신경 손상 등을 유발하는 것으로 알려져 있다[14].

최근 기능성 생리활성 성분을 함유하고 있는 식물 자원이나 식품 성분에 관한 연구가 국내·외적으로 활발하게 이루어지 고 있다. 이에 따라 식물 자원에 포함된 화합물에 관심이 집중

*Corresponding author Tel : +82-53-850-3774, Fax : +82-53-850-3774

E-mail : toto0818@cu.ac.kr
되고 있고 그에 따른 연구 결과도 다양하게 보고되고 있다[5]. Septicine (6,7-Bis(3,4-dimethoxyphenyl)-1,2,3,5,8,8a-hexahydroindolizine, $\mathrm{C}_{24} \mathrm{H}_{29} \mathrm{NO}_{4}$, Fig. 1)은 박주과리과(Asclepiadaceae) 왜박주가리속(Tylophora)에 속하는 Tylophora asthmatica, Tylophora ovata 등에 함유되어 있는 alkaloids로 해열, 항균작 용 등이 있는 것으로 알려져 있다[8]. 현재 septicine에 관한 연구의 대부분은 그 효율적인 합성법에 관한 것으로[2,10], septicine의 생리활성에 대한 연구는 매우 미비한 상태로, Tylophora ovata로부터 분리된 septicine 및 septicine alkaloids 가 LPS와 interferon- $\gamma$ 로 자극한 생쥐의 대식세포의 NO 생성 을 억제한다는 연구가 유일하다[8]. 따라서 septicine의 생리활 성에 대한 다양한 연구는 절실히 필요하다고 할 수 있다. 본 연구에서는 septicine의 생리활성에 대한 연구의 일환으로, 그 항염증작용을 중점적으로 조사하였다. Septicine의 항염증작 용을 검토하기 위하여 생쥐의 대식세포주인 RAW264.7 세포 에 LPS를 처리하여 염증반응을 유도한 후, $\mathrm{NO}$ 의 생성, 염증성<smiles>COc1ccc(C2=C(c3ccc(OC)c(OC)c3)CN3CCC[C@H]3C2)cc1OC</smiles>

Fig. 1. Chemical structure of septicine. 
cytokine인 tumor necrosis factor (TNF)-a, interleukin (IL)-6 의 분비량, $\mathrm{iNOS}$ 의 발현정도 등을 조사하여 염증반응에 미치 는 영향을 관찰하였다.

\section{재료 및 방법}

\section{시약}

Septicine은 Alexis biochemicals (San Diego, CA, USA)에 서 구입하여 사용하였다. LPS 및 $\beta$-actin 항체는 SigmaAldrich (St. Louis, MO, USA)에서 구입하였다. Dulbecco's Modified Eagle's Medium (DMEM), 10\% 소태아혈청(Fetal Bovine Serum, FBS), 페니실린(penicillin) 및 스트렙토마이신 (streptomycin)은 Hyclone (Logan, UT, USA)에서 구입하였 다. Cell Titer 96 AQueous One Solution과 Griess reagent system은 Promega (Madison, WI, USA)에서 구입하였고, $\mathrm{PGE}_{2}$ enzyme-linked immunosorbent assay (ELISA) kit는 R\&D Systems (Minneapolis, MI, USA)에서 구입하였다. TNF- $a$ 와 IL-6 ELISA kit는 eBioscience (San Diego, CA, USA)에서 구입 하여 사용하였다. COX-2와 iNOS 항체는 BD Biosciences (San Diego, CA, USA)에서 구입하여 사용하였다.

\section{세포배양}

생쥐의 대식세포주인 RAW264.7 세포는 한국세포주은행 (Seoul, Korea)에서 분양 받아 DMEM 배양액에 $10 \% \mathrm{FBS}$ 와 $100 \mathrm{Unit} / \mathrm{ml}$ streptomycin과 $100 \mathrm{\mu g} / \mathrm{ml}$ penicillin을 첨가한 배양액을 사용하였다. 세포는 $5 \%$ 의 $\mathrm{CO}_{2}$ 를 포함한 $37^{\circ} \mathrm{C}$ 의 포 화습도 공기조건 하에서 배양하였다.

\section{세포증식 측정}

세포증식을 측정하기 위해 RAW264.7 세포를 96-well plate 에 $2 \times 10^{4}$ cells/well이 되도록 분주한 후 12 시간 배양하였다. 세포배양액을 이용하여 septicine의최고 농도를 2,000 nM로 하여 RAW264.7 세포에 처리하여 24시간 배양한 후, Cell Titer 96AQueous One solution assay (Promega)를 이용하여 세포 증식에 미치는 septicine 효과를 MTS 방법으로 측정하였다 [15].

\section{Nitric oxide (NO) 측정}

RAW264.7 세포로부터 생성되는 NO의 양을 세포 배양핵 중 존재하는 $\mathrm{NO}_{2}{ }^{-}$의 형태로 Griess reagent 반응법을 이용하 여 측정하였다. 즉 RAW264.7 세포를 48-well plate에 $2.5 \times 10^{5}$ cells/well이 되도록 분주한 후 12시간 배양한 후에 septicine $31.2,62.5,125,250,500,1,000 \mathrm{nM}$ 과 LPS $(100 \mathrm{ng} / \mathrm{ml})$ 를 동시 처리 또는 LPS를 단독 처리하여 24시간 배양하였다. 세포 배 양액을 얻어 nitrite양의 측정은 Griess reagent system (Promega)을 이용하여 측정하였다.

\section{IL-6 및 TNF- $a$ 측정}

RAW264.7 세포를 48-well plate에 $2.5 \times 10^{5}$ cells/well이 되 도록 분주하여 12 시간 배양한 후에 septicine $31.2,62.5,125$, $250,500,1,000 \mathrm{nM}$ 과 LPS $(100 \mathrm{ng} / \mathrm{ml})$ 을 동시 처리 또는 LPS 를 단독 처리하여 24 시간 배양 후, 배양액 중에 존재하는 TNF$a$ 와 IL-6의 양을 각 ELISA kit (eBioscience)을 이용하여 제조 사의 분석방법에 의해 측정하였다.

\section{iNOS 단백질 발현 양 측정}

RAW264.7 세포를 $60 \mathrm{~mm}$ 배양접시에 $2 \times 10^{6}$ cells이 되도록 분주한 후 12 시간 배양하였다. Septicine $62.5,125,250,500$ $\mathrm{nM}$ 과 LPS $100 \mathrm{ng} / \mathrm{ml}$ 을 동시 처리 또는 LPS를 단독 처리하여 24시간 배양한 후, Pro-prep protein extraction solution (iNtRon, Korea)을 이용하여 세포 내 단백질을 얻었다. BCA assay reagent (Thermo, Pierce)로 단백질의 농도를 측정한 후, 동량 $(40 \mu \mathrm{g})$ 의 단백질을 $8 \%$ SDS-PAGE gel에서 전기영동 후, nitrocellulose membrane (Roche, Indianapolis, IN)으로 옮겼 다. 항체의 비 특이적 결합을 억제시키기 위해 membrane을 $3 \%$ 탈지분유액이 포함된 TBST ( $50 \mathrm{mM}$ Tris-HCl, $\mathrm{pH} 7.5,150$ $\mathrm{mM} \mathrm{NaCl}, 0.1 \%$ Tween-20)로 1시간 실온에서 배양하였다. 그 후, $\mathrm{iNOS}$ 의 항체를 이용하여 $4^{\circ} \mathrm{C}$ 에서 12 시간 반응시켰다. iNOS 발현 양은 horseradish peroxidase (HRP)가 붙어있는 secondary antibodies (Santa Cruz Biotechnology, Santa $\mathrm{Cruz}, \mathrm{Ca}, \mathrm{USA}$ )로 실온에서 2시간 반응 후 Chromogenic Substrate (Invitrogen, Carlsbad, California)를 이용하여 확인 하였다.

\section{자료의 통계처리}

자료의 통계처리는 GraphPad Prism 4.0 (GraphPad software, San Diego, CA)프로그램을 이용하였다. 시험물질 처리 군과 대조군의 차이를 비교하기 위하여 $t$ tests를 이용하였다. $p<0.05$ 일 때만 통계적 유의성이 있는 것으로 판단하였다.

\section{결과 및 고찰}

면역세포 중 대식세포는 내재면역반응과 적응면역반응에 있어 중요한 역할을 담당하고 있으며, 내독소, mitogen, virus 등에 의해서 활성화 된다[3]. 활성화된 대식세포는 탐식작용을 하고 면역반응을 조절하는 다양한 물질을 분비한다[3]. 이들 물질 중에는 $\mathrm{NO}$ 와 같은 산소대사산물, $\mathrm{PG}$ 와 같은 지질대사 물 및 단백질류(cytokine 및 chemokine) 등이 있으며, 대식세 포는 이들을 생산 - 분비하여 다양한 생체기능을 수행하게 된 다. 따라서 본 연구에서는 생쥐의 대식세포주인 RAW264.7 세 포를 이용하여 septicine의 항염증작용을 관찰하였다.

먼저, septicine의 RAW264.7 세포 증식에 대한 영향을 알아 보기 위해 2,000 nM의 농도를 최고농도로 하여 RAW264.7 세 
포에 처리하였다. Septicine을 처리한 24시간 후 세포독성 여 부를 MTS 방법으로 확인 한 결과, 2,000 nM의 septicine처리 는 RAW264.7 세포의 증식을 유의적으로 억제하였으나 1,000 $\mathrm{nM}$ 까지의 septicine의 처리는 세포증식에의 영향을 끼치지 않 은 것을 확인 할 수 있었다(Fig. 2). 따라서 이하의 실험에서는 septicine이 RAW264.7 세포의 세포생존율에 영향을 주지 않 는 $1,000 \mathrm{nM}$ 이하의 농도를 사용하여 실험을 진행하였다.

내독소로 잘 알려진 LPS는 그람음성균의 세포 외막에 존재 하며, 대식세포 또는 단핵구에 존재하는 염증성 매개물질의 생성을 증강시키는 것으로 알려져 있다[12]. LPS는 대식세포 에 존재하는 toll-like receptor (TLR)-4를 활성화시켜 세포내 정보전달 흐름(intracellular signaling cascades)의 활성이 유

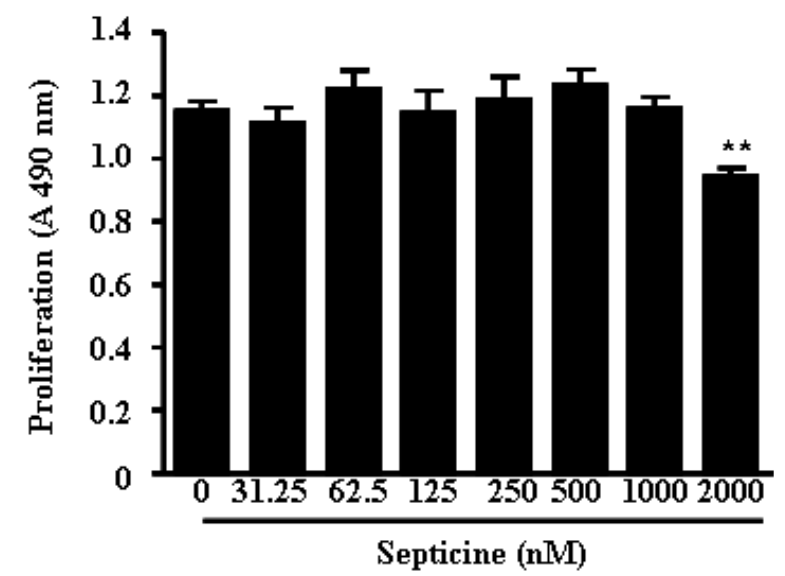

Fig. 2. Effects of septicine on murine macrophage viability. RAW264.7 cells were treated with indicated concentrations of septicine for $24 \mathrm{hr}$, and proliferation was determined as described in Materials and Methods. Statistical significance is based on the difference when compared with untreated cells $\left({ }^{* *} p<0.01\right)$.
도되고 결과적으로 다양하면서도 독특한 염증 및 면역반응 관련 유전자들의 전사합성이 이루어진다[12]. 따라서 본 연구 에서는 LPS로 RAW264.7 세포를 자극하여 염증반응을 유도하 였다.

LPS에 의해 활성화된 RAW264.7 세포의 배양액 중에 생성 된 nitrite의 양을 septicine을 대상으로 NO 생성 저해활성을 조사하였다. 그 결과 septicine $(31.2 \sim 1,000 \mathrm{nM})$ 의 처리가 LPS 에 의해 생산되는 $\mathrm{NO}$ 의 생성을 농도 의존적으로 억제함을 확인 할 수 있었다(Fig. 3A).

IL-6 및 TNF-a로 대표되는 염증성 cytokine은 염증 반응을 매개하는 물질로 특히 초기 염증 반응에 깊이 관여하고 있는 것으로 알려져 있다[4]. 주로 단핵구나 대식세포에서 분비되는 IL-6는 B세포가 형질세포로 분화되는 마지막 단계를 활성화시 키고, 항체의 분비를 촉진한다. 또한 IL-6는 염증병소에서 증 가하는 것으로 알려져 있다[4,11]. TNF- $a$ 는 LPS 반응의 주요 매개체로 내재면역반응의 중요한 역할을 담당한다. 대식세포 나 비만세포에서 분비되는 TNF-a는 암세포에 세포독성을 나 타내며, 만성염증반응과 관련되어 있다[4,9].

RAW264.7 세포에서 LPS 자극에 의해 생성되는 염증성 사 이토카인에 대한 septicine의 영향을 조사하기 위해 다양한 농 도의 septicine과 LPS $(100 \mathrm{ng} / \mathrm{ml})$ 를 처리한 후, 세포 배양액으 로 분비된 IL-6 및 TNF-a를 측정하였다. IL-6의 경우 $125 \mathrm{nM}$ 및 그 이상의 농도의 septicine의 처리가 IL-6의 분비를 유의적 으로 억제하였으며(Fig. 3B), TNF- $a$ 는 septicine $500 \mathrm{nM}$ 및 그 이상의 농도에서부터 유의적으로 감소하였다(Fig. $3 \mathrm{C}$ ). 이와 같은 결과는 LPS에 의해 활성화된 RAW264.7 세포에서의 septicine의 처리는 염증성 매개물질(NO, IL-6 및 TNF-a)의 생성을 억제함으로 항염증 활성을 나타낸다는 것을 시사하고 있다.

염증반응의 대표적인 매개물질인 $\mathrm{NO}$ 는 $\mathrm{iNOS}$ 라는 효소에
A

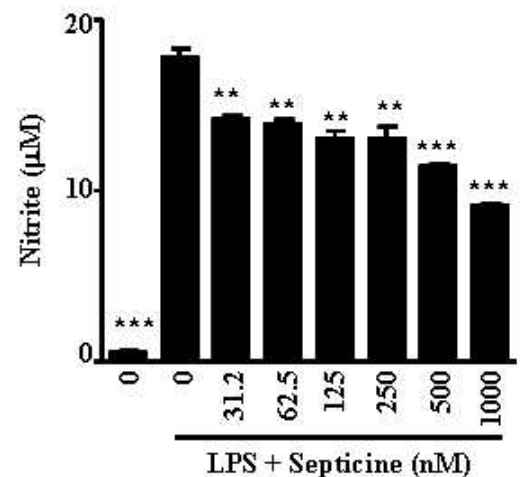

B

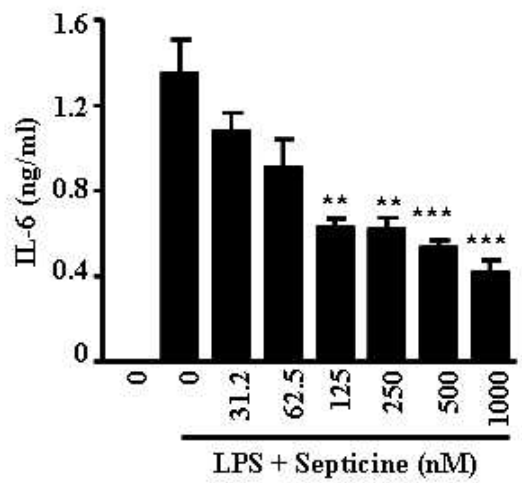

C

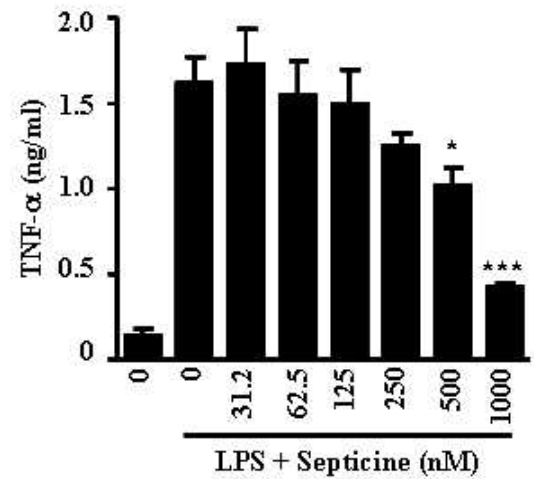

Fig. 3. Effects of septicine on LPS-induced NO, IL-6 and TNF-a production. RAW264.7 cells were treated with indicated concentrations of septicine in the presence of $100 \mathrm{ng} / \mathrm{ml}$ of LPS or with LPS alone for $24 \mathrm{hr}$, and NO (A), IL-6 (B) and TNF-a (C) release were determined. The results are reported as mean $\pm \mathrm{SE}$ of four independent experiments in triplicate. Statistical significance is based on the difference when compared with LPS-stimulated cells $\left({ }^{*} p<0.05,{ }^{* *} p<0.01,{ }^{* * *} p<0.001\right)$. 
의해 생합성 된다[7]. Septicine의 처리가 LPS로 유도된 NO의 분비를 억제하였기 때문에(Fig. $3 \mathrm{~A}), \mathrm{NO}$ 의 생성을 매개하는 iNOS의 발현에 대한 septicine의 영향을 조사하였다.

RAW264.7 세포에 septicine 62.5, 125, 250, $500 \mathrm{nM}$ 과 LPS 100 $\mathrm{ng} / \mathrm{ml}$ 을 동시 처리 또는 LPS를 단독 처리하여 24 시간 배양하 여 Western blot으로 확인하였다. iNOS 단백질 발현 양의 변 화를 관찰한 결과, septicine의 처리는 농도 의존적으로 LPS에 의해 유도된 iNOS 단백질 발현 양을 감소시킴을 관찰 할 수 있었다(Fig. 4). 이러한 결과는 septicine의 의한 iNOS 단백질 발현 양의 감소가 $\mathrm{NO}$ 생성을 억제한다는 것을 시사하고 있다.

염증반응은 외부항원에 의해 활성화된 다양한 면역세포들 에 의해 매개되는 복잡한 과정이며, 대식세포는 LPS와 같은 염증유발불질에 의해 활성화되어 TRL-4의 발현을 자극한다 $[12,13,14]$. TLR-4는 LPS/CD14 복합체에 대한 막 투과성 수용 체로 염증유도의 단계적 과정을 활성화 한다[12,13,14]. 이러한 기전을 통하여 $\mathrm{NO}$ 를 포함하는 염증매개물질이 유도된다.

본 연구에서는 대식세포인 RAW264.7 세포를 LPS에 노출 시키면 현저한 NO 및 염증성 사이토카인의 생성을 확인 할 수 있는데 septicine은 이러한 염증매개물질의 생성억제를 세 포독성이 없는 농도에서 억제 하였다. 위의 사실에 기초하여 NO 생성저해의 기전을 알아보기 위해 Western blot을 이용하 여 $\mathrm{iNOS}$ 의 발현을 분석한 결과 NO 생성억제와 유사한 경향 을 나타냄으로써 NO의 생성 억제는 $\mathrm{iNOS}$ 의 발현저해를 경유 한 것임을 알 수 있었다. 이상의 결과를 요약하면 septicine은
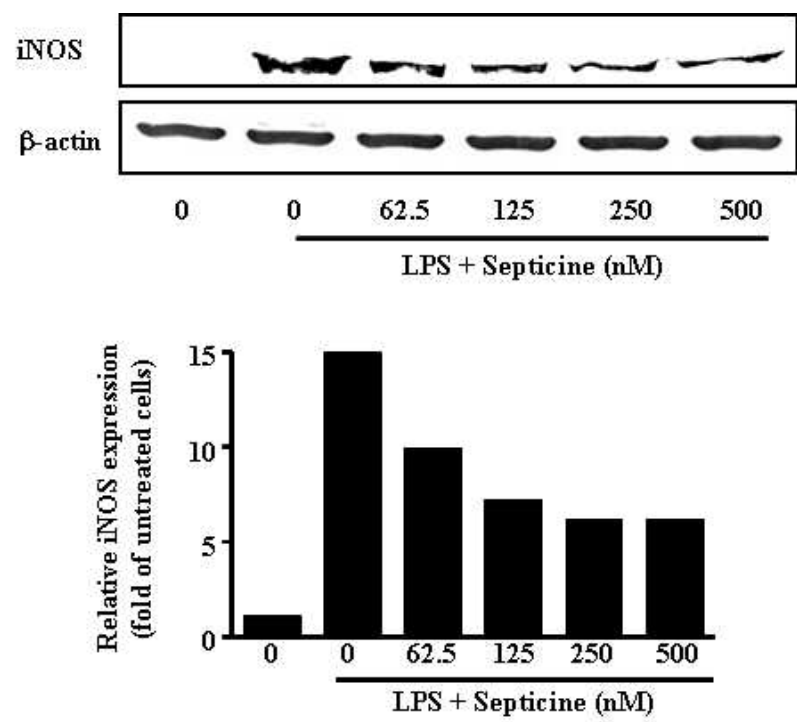

Fig. 4. Effects of septicine on LPS-induced iNOS expression. RAW264.7 cells treated the same as in Fig. 3. Forty $\mu \mathrm{g}$ of protein obtained from each cell lysate was resolved on $8 \%$ SDS-PAGE for iNOS determination. b-actin expression is shown as a loading control. The bands were quantified using NIH image analysis software and their relative intensity was expressed as fold against the image of the untreated cells.
염증반응의 주체가 되는 대식세포에서 LPS에 의해 유도되는 NO, TNF-a, IL-6 등과 같은 염증매개물질의 생성을 억제함으 로 항염증 작용을 나타내는 것으로 보인다. 차후 septicine의 항염증 작용의 기전 및 in vivo에서의 septicine의 항염증 작용 에 대한 검증이 필요할 것으로 사료된다.

\section{감사의 글}

이 논문은 2010년도 정부(교육과학기술부)의 재원으로 한 한국연구재단의 지원을 받아 수행된 기초연구사업 임(No. 2010-0004728)

\section{References}

1. Chen, G. Y. and G. Nunez. 2010. Sterile inflammation: sensing and reacting to damage. Nat. Rev. Immunol. 10, 826-837.

2. Comins, D. L., X. Chen, and L. A. Morgan. 1997. Enantiopure $\mathrm{N}$-acyldihydropyridones as synthetic intermediates: asymmetric synthesis of (-)-septicine and (-)-tylophorine. J. Org. Chem 62, 7435-7438.

3. Fujiwara, N. and K. Kobayashi. 2005. Macrophages in inflammation. Curr. Drug Targets Inflamm Allergy 4, 281-286.

4. Gehr, G., T. Braun, and W. Lesslauer. 1992. Cytokines, receptors, and inhibitors. Clin. Investig. 70, 64-69.

5. Haustedt, L. O., C. Mang, K. Siems, and H. Schiewe. 2006. Rational approaches to natural-product-based drug design. Curr. Opin. Drug Discov. Devel. 9, 445-462.

6. Kohl, J. 2006. Self, non-self, and danger: a complementary view. Adv. Exp. Med Biol. 586, 71-94.

7. Lee, B. G., S. H. Kim, O. P. Zee, K. R. Lee, H. Y. Lee, J. W. Han, and H. W. Lee. 2000. Suppression of inducible nitric oxide synthase expression in RAW 264.7 macrophages by two-carboline alkaloids extracted from Melia azedarach. Eur. J. Pharmacol. 406, 301-309.

8. Lee, Y. Z., C. W. Huang, C. W. Yang, H. Y. Hsu, I. J. Kang, Y. S. Chao, I. S. Chen, H. Y. Chang, and S. J. Lee. 2011. Isolation and biological activities of phenanthroindolizidine and septicine alkaloids from the formosan Tylophora ovata Planta. Med DOI: 10.1055/s-0030-1271199.

9. MacEwan, D. J. 2002. TNF receptor subtype signalling: differences and cellular consequences. Cell Signal. 14, 477-492.

10. Michael, J. P. 2001. Indolizidine and quinolizidine alkaloids. Nat. Prod Rep. 18, 520-542.

11. Scheller, J., A. Chalaris, D. Schmidt-Arras, and S. Rose-John. 2011. The pro- and anti-inflammatory properties of the cytokine interleukin-6. Biochim Biophys. Acta. 1813, 878-888.

12. Tsan, M. F. and B. Gao. 2007. Pathogen-associated molecular pattern contamination as putative endogenous ligands of Toll-like receptors. J. Endotoxin Res. 13, 6-14.

13. Valledor, A. F., M. Comalada, L. F. Santamaria-Babi, J. Lloberas, and A. Celada. 2010. Macrophage proinflammatory activation and deactivation: a question of balance. $A d v$. Immunol. 108, 1-20. 
14. Zhang, X. and D. M. Mosser. 2008. Macrophage activation by endogenous danger signals. J. Pathol. 214, 161-178.

15. Zhou, G., M. C. Gingras, S. H.Liu, D. Li, Z. Li, R. L. Catania, K. M. Stehling, M. Li, G. Paganelli, R. A. Gibbs, F. J.
Demayo, W. E. Fisher, F. C. Brunicardi. 2011. The hypofunctional effect of P335L single nucleotide polymorphism on SSTR5 function. World J. Surg. 35, 715-724.

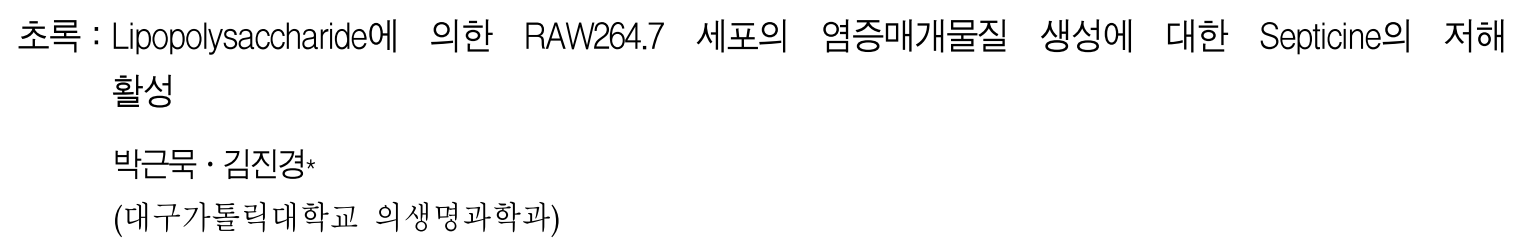

초록 : Lipopolysaccharide에 의한 RAW264.7 세포의 염증매개물질 생성에 대한 Septicine의 저해 활성

박근묵 · 김진경*

(대구가톨릭대학교 의생명과학과)

염증은 바이러스 등의 병원체 및 다양한 물리·화학적 스트레스에 의하여 일어나는 생체방어 반응이나, 과도 한 염증반응은 세포독성과 다양한 질환을 일으킨다. 따라서 염증반응에서 생성되는 과도한 염증매개물질들을 억 제함으로 다양한 염증질환을 예방, 치료 할 수 있다. 본 연구에서는 Tylophora asthmatica, Tylophora ovata 등에 함 유되어 있는 생리활성 성분인 septicine의 항염증 효과를 연구하였다. 생쥐의 대식세포주인 RAW264.7 세포에 lipopolysaccharide (LPS)를 처리하여 염증반응을 유도하고, septicine를 처리한 결과, septicine은 LPS 처리에 의 한 nitric oxide $(\mathrm{NO})$ 및 염증성 사이토카인의 분비를 현저히 억제시키는 것을 관찰 할 수 있었으며, $\mathrm{NO}$ 의 생합 성효소인 $\mathrm{iNOS}$ 단백질의 발현 또한 억제시킴을 확인 할 수 있었다. 이러한 연구결과는 염증반응을 조절하는 후 보물질로써의 septicine의 가능성을 보여주는 것이다. 